\title{
Fournier's gangrene: A retrospective analysis of 25 patients
}

\author{
Metin Yücel, M.D., ${ }^{1}$ Adnan Özpek, M.D., ${ }^{1}$ Fatih Başak, M.D., ${ }^{1}$ Ali Kılıç, M.D.,, ${ }^{1}$ Ethem Ünal, M.D., ${ }^{1}$ \\ Sema Yüksekdağ, M.D., ${ }^{1}$ Aylin Acar, M.D., ${ }^{1}$ Gürhan Baş, M.D. ${ }^{2}$
}

1'Department of General Surgery, Ümraniye Training and Research Hospital, İstanbul-Turkey

${ }^{2}$ Department of General Surgery, Medeniyet University Faculty of Medicine, İstanbul-Turkey

\begin{abstract}
BACKGROUND: Fournier's gangrene is a surgical emergency that progresses rapidly and insidiously and results in high morbidity and mortality rates unless it is immediately diagnosed and managed. Here we analyze the outcomes of patients who were followed up and treated for Fournier's gangrene.

METHODS: We conducted a retrospective analysis of the medical data of 25 patients operated on for Fournier's gangrene between January 2010 and June 20I5. The diagnosis of Fournier's gangrene was made by performing a physical examination. Patients who had genital, perineal, and perianal tenderness; induration; cyanosis; gangrene; and subcutaneous crepitation were considered as having Fournier's gangrene. Following resuscitation, aggressive surgical debridement was performed and vacuum-assisted closure (VAC) was conducted in addition to debridement in select patient. Repeat debridements were performed as requirement.

RESULTS: This study included 25 patients. Fourteen patients (56\%) were females and II (44\%) were males. The mean age of the patients was 54.3 years (range: 27-82 years). The mean duration of hospital stay was 21.4 days; the mean number of debridements performed was 2.4 . Thirteen patients (52\%) had perianal abscesses, and 20 (80\%) had diabetes mellitus. All patients underwent extensive debridement; 16 patients (64\%) underwent VAC in addition to debridement. Patients undergoing VAC had significantly longer durations of hospital stay and a higher mean number of debridements performed $(p=0.004$ and $p=0.048$, respectively). An ostomy was made in one patient, and one patient died.
\end{abstract}

CONCLUSION: In Fournier's gangrene, early diagnosis, effective resuscitation, aggressive debridement, and VAC application in suitable cases may reduce the morbidity and mortality rates and the need for an ostomy.

Keywords: Aggressive surgical debridement; Fournier's gangrene; vacuum-assisted closure.

\section{INTRODUCTION}

Fournier's gangrene is a necrotizing fasciitis disease affecting the genital, perianal, and perineal regions and causes extensive soft tissue necrosis by rapidly progressing between fascial planes, when its diagnosis and management are delayed. This emergency surgical condition is associated with a high mortality rate. ${ }^{[1-5]}$ Urogenital and anorectal infections and trauma are the primary etiological factors of Fournier's gangrene. It is often a polymicrobial condition caused by various aero-

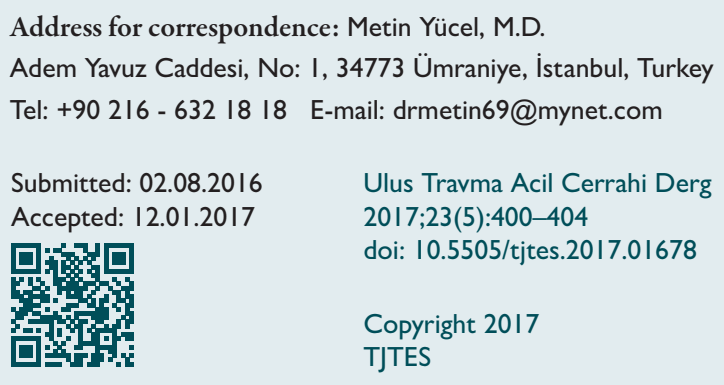

bic and anaerobic micro-organisms. ${ }^{[2,6-12]}$ Although Fournier's gangrene is more common among men and the elderly, it may affect both sexes and every age group. ${ }^{[5,8,9,13]}$

The basic principles of its management include broad-spectrum antibiotics and aggressive surgical debridement. ${ }^{[3,10]} \mathrm{De}-$ spite advances in its diagnosis and treatment, the mortality rate due to Fournier's gangrene remains as high as $16-50 \%$. [2,6,14-16] Here we analyze etiological and predisposing factors and outcomes associated with vacuum-assisted closure (VAC) in patients who were followed up and treated for Fournier's gangrene over a 5-year period at our clinic, Umraniye Training and Research Hospital, Istanbul, Turkey.

\section{MATERIALS AND METHODS}

We retrospectively reviewed the medical records of hospitalized patients operated on for Fournier's gangrene at our clinic between January 2010 and June 2015. The diagnosis of Fournier's gangrene was made by performing a physical examination. Patients with genital, perineal, and perianal ten- 
Table I. Impact of gender on outcome variables in patients with Fournier's gangrene

\begin{tabular}{|c|c|c|c|}
\hline & $\frac{\text { Male }}{\text { Mean } \pm S D}$ & $\frac{\text { Female }}{\text { Mean士SD }}$ & $\mathbf{p}$ \\
\hline Age & $42.0 \pm 9.8$ & $63.9 \pm 10.7$ & $0.001^{\prime}$ \\
\hline $\begin{array}{l}\text { Number of debridements } \\
\text { performed }\end{array}$ & $2.4 \pm 1.0$ & $2.4 \pm 1.6$ & $0.748^{2}$ \\
\hline Duration of hospital stay & $20.6 \pm 14.4$ & $22.1 \pm 16.4$ & $0.800^{\prime}$ \\
\hline
\end{tabular}

't-test; ${ }^{2}$ Mann Whitney test. SD: Standard deviation.

derness; induration; cyanosis; gangrene; and subcutaneous crepitation were considered to have Fournier's gangrene. The patients were admitted to the hospital ward, and resuscitation was initiated. Broad-spectrum antibiotics were administered.

The patients were operated on after they were stabilized and had provided informed consent. All infected necrotic tissues were debrided in the operation until the surgeon could observe living and bleeding tissues. The tissues were irrigated with hydrogen peroxide and povidone iodine during debridement. Repeat debridements were performed in patients with persistent infection and necrosis after the initial debridement. In complicated cases with extensive and deep necrosis, VAC was performed together with second debridement. In contrast, in healed patients, the defect was closed with primary sutures or a graft.

Patient with secondary anorectal tumors, perianal abscesses, or simple skin infections without Fournier's gangrene were not included. The demographic properties, predisposing factors, primary site of infection, number of debridements performed, number of patients who underwent VAC, and duration of hospital stay were analyzed.

\section{Statistical Analysis}

Statistical calculations were performed using IBM SPSS 22 software (IBM SPSS, USA). Variables were expressed as mean \pm standard deviation (SD) or median (range), depending on their distribution. Categorical variables were expressed as frequencies and percentages. Fisher's exact test was used for comparing continuous parametric variables. The t-test was used for the comparison of parametric variables with normal distribution. The Mann-Whitney $U$ test was used for the comparison of parametric variables that lacked normal distribution. Statistical results were reported within $95 \%$ confidence interval. Differences were considered statistically significant when the $p$-value was less than 0.05 .

\section{RESULTS}

A total of 25 patients were enrolled. Among them, I4 (56\%) were females and II (44\%) were males. The mean age of the patients was $54.3 \pm 15.0$ years (range: $27-82$ years). The female patients had a significantly higher mean age $(p=0.00 \mathrm{I})$. The mean duration of hospital stay was $21.4 \pm 15.2$ days (range: 4-55 days); the difference between females and males was not statistically significant $(p=0.800)$. The mean number of debridements performed was $2.4 \pm$ I.4 (range: I-6); the difference between genders was not statistically significant $(p=0.748)$ (Table I).

The etiological factor was a perianal abscess in 13 patients (52\%). When the patients with and those without a perianal abscess were compared for the mean duration of hospital stay and the mean number of debridements performed, there was no statistical difference $(p=0.40 \mathrm{I}$ and $p=0.273$, respectively) (Table 2). A urogenital infection was detected in four patients (16\%); the etiology remained unclear in eight patients (32\%).

Twenty patients (80\%) had diabetes mellitus (DM). Diabetic and non-diabetic patients showed no statistical difference in the mean duration of hospital stay and the mean number of debridements performed $(p=0.235$ and $p=0.720$, respectively) (Table 3). Three patients (12\%) were obese and two of them also had DM.

Extensive aggressive debridement was performed in all pa-

Table 2. Comparison of patients who had perianal abscess and those who had non-perianal abscess

\begin{tabular}{|c|c|c|c|c|c|c|c|}
\hline & \multicolumn{3}{|c|}{ Perianal abscess } & \multicolumn{3}{|c|}{ Non-perianal abscess } & \multirow[t]{2}{*}{$\mathbf{p}$} \\
\hline & $\mathbf{n}$ & $\%$ & Mean \pm SD & $\mathbf{n}$ & $\%$ & Mean $\pm S D$ & \\
\hline Age, & & & $52.4 \pm 12.8$ & & & $56.3 \pm 17.5$ & $0.523^{\prime}$ \\
\hline \multicolumn{8}{|l|}{ Gender } \\
\hline Male & 6 & 55 & & 5 & 45 & & $1.000^{2}$ \\
\hline Female & 7 & 50 & & 7 & 50 & & \\
\hline Number of debridements performed & & & $2.7 \pm 1.6$ & & & $2.2 \pm 1.1$ & $0.273^{\prime}$ \\
\hline Duration of hospital stay & & & $18.9 \pm 14.3$ & & & $24.2 \pm 16.4$ & $0.401^{\prime}$ \\
\hline
\end{tabular}


Table 3. Impact of diabetes mellitus on outcome variables in patients with Fournier's gangrene

\begin{tabular}{|c|c|c|c|}
\hline & Diabetic & Non-diabetic & $\mathbf{p}$ \\
\hline & Mean $\pm S D$ & Mean士SD & \\
\hline Age & $56.3 \pm 15.0$ & $46.2 \pm 13.7$ & $0.184^{\prime}$ \\
\hline $\begin{array}{l}\text { Number of debridements } \\
\text { performed }\end{array}$ & $2.4 \pm 1.4$ & $2.6 \pm 1.5$ & $0.720^{2}$ \\
\hline Duration of hospital stay & $23.6 \pm 16.1$ & $13.0 \pm 7.3$ & $0.235^{2}$ \\
\hline
\end{tabular}

't-test; ${ }^{2}$ Mann-Whitney test. SD: Standard deviation.

Table 4. Comparison of patients who underwent VAC and those who did not undergo VAC

\begin{tabular}{lccccc}
\hline & VAC & & Without VAC & p \\
\cline { 2 - 2 } & Mean \pm SD & & Mean \pm SD & \\
\hline Age & $55.0 \pm 13.9$ & & $53.0 \pm 17.7$ & 0.7571 \\
Number of debridements & $2.8 \pm 1.5$ & & $1.7 \pm 0.7$ & $0.048^{2}$ \\
performed & & & & \\
Duration of hospital stay & $26.4 \pm 14.5$ & & $12.6 \pm 12.7$ & $0.004^{2}$ \\
\hline
\end{tabular}

't-test; ${ }^{2}$ Mann-Whitney test. VAC: Vacuum assisted closure; SD: Standard deviation.

tients (Fig. I). VAC was added to debridement in 16 patients (64\%). The mean duration of hospital stay was $26.4 \pm$ I 4.5 days (range: 8-55) in patients who underwent VAC and I 2.6 12.7 days (range: 4-44) in those who did not. The mean number of debridements performed was $2.8 \pm 1.5$ (range: I-6) in patients who underwent VAC and I.7 \pm 0.7 (range: $1-3$ ) in those who did not. Patients who underwent VAC had a significantly longer mean duration of hospital stay and higher mean number of debridements performed $(p=0.004$ and $p=0.048$, respectively) (Table 4).

One patient (4\%) required an ostomy because of extensive perianal and sphincter involvement. One VAC patient (4\%) who had a perianal abscess and DM died.

\section{DISCUSSION}

Early diagnosis is central to the successful treatment of Fournier's gangrene and a favorable prognosis. Although radiological techniques such as X-rays, ultrasonography, computed tomography, and magnetic resonance imaging are helpful for making a diagnosis, Fournier's gangrene is typically diagnosed by performing a physical examination. ${ }^{[13,14,17,18]}$ Pain, inflammation, edema, necrosis, and subcutaneous crepitation are often noted in the involved region upon performing a physical examination. Fournier's gangrene was diagnosed by performing a physical examination in our study.

Although Fournier's gangrene may affect both sexes and occur at any age, it is more common among men and the elderly. ${ }^{[5,6,9,13]}$ The reason for its decreased prevalence in women is explained by the simpler drainage of the female perineum via the vaginal route. Furthermore, many reports on this condition have been published by urology clinics in which men predominated in samples, which led to males being over-represented in reports. A study by Eke focused on I 726 patients with Fournier's gangrene; the author found that the condition was 10 times more common in men. ${ }^{[7]}$ The reason for the higher incidence of Fournier's gangrene among the elderly may be increased susceptibility to the disease due to a weakened immune response secondary to chronic disorders and an increased prevalence of circulatory disturbances due to more common vascular pathologies at advanced ages. Women were more numerous than men in our study; the female-to-male ratio was 1.27, and the mean age of our patients was 54.3 years.

DM, obesity, cancer, alcoholism, advanced age, poor hygiene, malnutrition, trauma, liver disease, renal failure, and other conditions suppressing immune functions are predisposing factors for Fournier's gangrene. ${ }^{[2,3,12,19,20]}$ Among these factors, DM is the most common. ${ }^{[2,4,6,7,9,12,13,15]}$ Diabetes leads to increased susceptibility to infections owing to the suppression
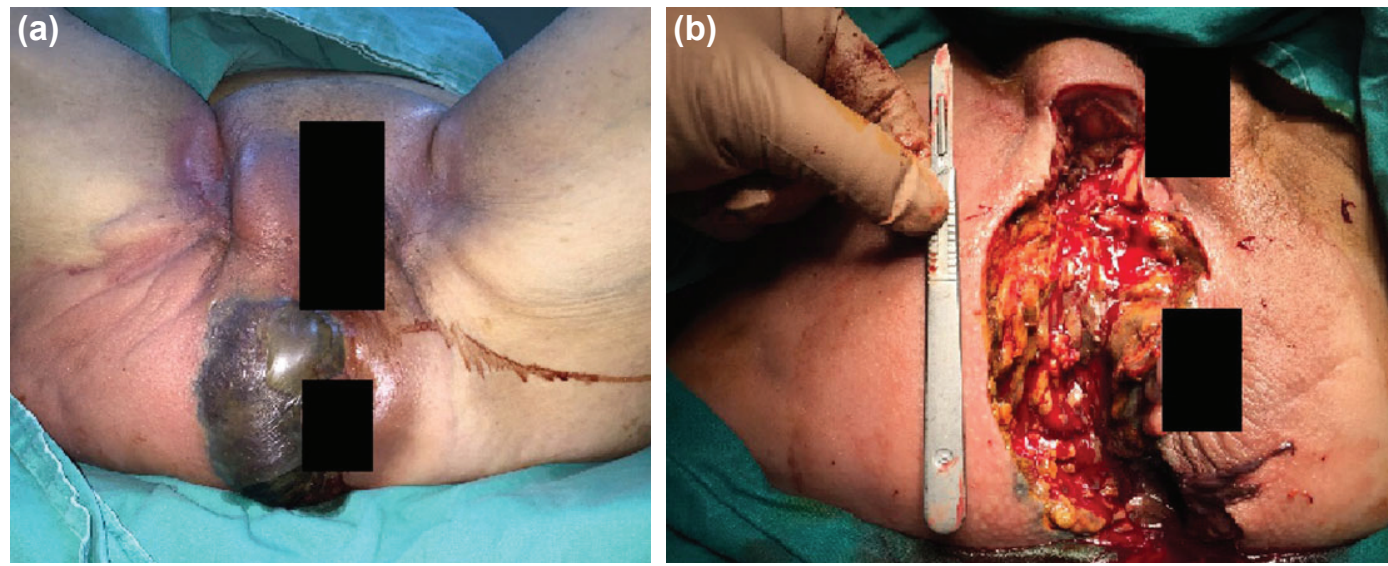

Figure 1. A patient who had Fournier gangrene (a) and aggressive surgical debridement (b). 
of chemotaxis, phagocytosis, and immune functions. Most of our study population (80\%) was diabetic.

Etiological factors for Fournier's gangrene include perineal, urogenital, and anorectal disorders as well as surgical interventions in these regions. Fournier's gangrene may also develop due to the spreading of an abdominal or retroperitoneal infection. In women, infections in the episiotomy region during the postpartum period may also cause Fournier's gangrene. Many studies have shown that perianal infections are the most common etiological factor in Fournier's gangrene. $[2,6,9,11,14]$ In our study, $52 \%$ of the patients had a perianal origin, and $16 \%$ had a urogenital origin; no clear etiology could be revealed in $32 \%$ of the patients due to the lack of records.

An effective resuscitation, wide-spectrum antibiotherapy, and aggressive debridement of necrotic tissues form the foundation of successful therapy. ${ }^{[3,7,8,10]}$ All necrotic and infected tissues should be debrided until healthy tissues can been observed. In patients in whom a single attempt of debridement was unsuccessful, repeat procedures should be performed until the infection is brought under control. According to the literature data, the required number of debridements ranges from 3.I to 7.3..$^{[2,6,14]}$ The mean number of debridements performed in our study was 2.4 .

Using VAC for Fournier's gangrene provides efficient wound care, reduces edema, augments blood flow, and hastens tissue healing. It is comfortable for patients and decreases pain and the required number of wound dressings. VAC enables more comfortable mobilization and reduces the duration of hospital stay. ${ }^{[4,12,21-23]}$ We performed VAC in addition to debridement in $64 \%$ of our patients. The mean duration of hospital stay was 26.43 days in our cohort, and the mean number of debridements performed was $2.8 \mathrm{I}$ in patients who underwent VAC. These numbers were higher than those in patients who did not undergo VAC. This finding is likely associated with the increased complexity of patients in whom VAC was performed.

There is no general consensus for performing colostomy in Fournier's gangrene. Some authors have recommended performing colostomy in case of extensive sphincter involvement, colonic or rectal perforation, or large perineal wounds. [2,6,9-11,15,24] In our study group, performing colostomy was necessary in only one patient due to extensive perianal and sphincter involvement. The low rate of colostomy in our series was attributed to the extensive use of VAC, particularly in complicated cases. We believe that an ostomy should be made in select patients for managing Fournier's gangrene.

The prognosis of Fournier's disease depends on its early diagnosis and treatment. Delays in the diagnosis and treatment, primary anorectal disease, advanced age, female gender, DM, malignant disorders, multiple organ failure at admission, and a high Fournier's gangrene index are predictors of a poor prog- nosis. ${ }^{[3,12,20]}$ Despite advances in its diagnosis and treatment, the mortality rates associated with Fournier's gangrene remains as high as $16-50 \% .^{[2,6,10,14]}$ Unfortunately, a 70-year-old woman with a perianal abscess and diabetes died in our study. In our opinion, the low mortality rate in our patients was due to performing aggressive surgical debridement and VAC.

As our study was retrospective, some patient data could not be accessed, which did not allow the calculation of the Fournier gangrene's index. In some patients, we were also unable to determine etiological and predisposing factors. These factors constitute the limitations of our study.

In conclusion, Fournier's gangrene is a surgical emergency that develops acutely and progresses rapidly and insidiously. It is associated with pronounced morbidity and mortality rates when its diagnosis and management are delayed. We found that effective resuscitation, aggressive surgical debridement, and VAC in suitable cases provide controlled wound care and reduce morbidity and mortality rates and the need for an ostomy.

\section{Funding}

The authors declared that this study was not funded by any company or person.

\section{Informed Consent}

Informed consent was obtained from all patients.

Conflict of interest: None declared.

\section{REFERENCES}

1. Geraci G, Pisello F, Lupo F, Cajozzo M, Sciume C, Modica G. Fournier's gangrene: case report and review of recent literature. Ann Ital Chir 2004;5:97-106.

2. Canbaz H, Caglikülekci M, Altun U, Dirlik M, Türkmenoglu O, Tasdelen B, et al. Fournier's gangrene: analysis of risk factors affecting the prognosis and cost of therapy in 18 cases. Ulus Travma Acil Cerrahi Derg 2010;16:71-6.

3. Taviloglu K, Cabioglu N, Cagatay A, Yanar H, Ertekin C, Baspinar I, et al. Idiopathic necrotizing fasciitis: risk factors and strategies for management. Am Surg 2005;71:315-20.

4. Oguz A, Gümüş M, Turkoglu A, Bozdag Z, Ülger BV, Agacayak E, et al. Fournier's Gangrene: A summary of 10 years of clinical experience. Int Surg 2015;5:934-41. [CrossRef]

5. Erdogan A, Aydogan I, Senol K, Uckan EM, Ersoz S, Tez M. Simple scoring system for prediction of mortality in Fournier's gangrene. Eur J Trauma Emerg Surg 2016;42:513-8. [CrossRef]

6. Oymacı E, Coskun A, Yakan S, Erkan N, Ucar AD, Yıldırım M. Evaluation of factors affecting mortality in Fournier's Gangrene: Retrospective clinical study of sixteen cases. Ulusal Cer Derg 2014;30:85-9. [CrossRef]

7. Eke N. Fournier's gangrene: a review of 1726 cases. Br J Surg 2000;87:718-28. [CrossRef]

8. Smith GL, Bunker CB, Dinneen MD. Fournier's gangrene. Br J Urol 1998;81:347-55. [CrossRef]

9. Korkut M, Icoz G, Dayangac M, Akgün E, Yeniay L, Erdogan O, et al. 
Outcome analysis in patients with Fournier's gangrene: report of 45 cases. Dis Colon Rectum 2003;46:649-52. [CrossRef]

10. Yanar H, Taviloglu K, Ertekin C, Guloglu R, Zorba U, Cabioglu N, et al. Fournier's gangrene: risk factors and strategies for management. World J Surg 2006;30:1750-4. [CrossRef]

11. Morpurgo E, Galandiuk S. Fournier's gangrene. Surg Clin North Am 2002;82:1213-24. [CrossRef]

12. Czymek R, Schmidt A, Eckmann C, Bouchard R, Wulff B, Laubert T, et al. Fournier's gangrene: vacuum-assisted closure versus conventional dressings. Am J Surg 2009;197:168-76. [CrossRef]

13. Mallikarjuna MN, Vijayakumar A, Patil VS, Shivswamy BS. Fournier's gangrene: Current Practices. ISRN Surg 2012;2012:937-42. [CrossRef]

14. Benjelloun EB, Souiki T, Yakla N, Ousadden A, Mazaz K, Louchi A, et al. Fournier's gangrene: our experience with 50 patients and analysis of factors affecting mortality. World J Emerg Surg 2013;8:13. [CrossRef]

15. Yilmazlar T, Isık O, Ozturk E, Ozer A, Gulcu B, Ercan I. Fournier's gangrene: Review of 120 patients and predictors of mortality. Ulus Travma Acil Cerrahi Derg 2014;20:333-7. [CrossRef]

16. Furr J, Watts T, Street R, Cross B, Slobodov G, Patel S. Contemporary trends in the inpatients management of Fournier's gangrene: Predictors of length of stay and mortality based on population-based sample. Urology 2017;102:79-84. [CrossRef]
17. Heiner JD, Baldwin K, Laselle B. Fournier gangrene: rapid diagnosis with bedside ultrasonography. CJEM 2010;12:528-9. [CrossRef]

18. Levenson RB, Singh AK, Novelline RA. Fournier gangrene: role of imaging. Radiographics 2008;28:519-28. [CrossRef]

19. Norton KS, Johnson LW, Perry T, Perry KH, Sehon JK, Zibari GB. Management of Fournier's gangrene: an eleven year retrospective analysis of early recognition, diagnosis, and treatment. Am Surg 2002;68:709-13.

20. Sorensen MD, Krieger JN, Rivara FP, Klein MB, Wessells H. Fournier's gangrene: management and mortality predictors in a population based study. J Urol 2009;182:2742-7. [CrossRef]

21. Assenza M, Cozza V, Sacco E, Clementi I, TarantinoB, Passafiume F, et al. VAC (Vacuum Assisted Closure) treatment in Fournier's gangrene: personal experience and literature review. Clin Ter 2011;162:1-5.

22. Ozturk E, Ozguc H, Yilmazlar T. The use of vacuum assisted closure therapy in the management of Fournier's gangrene. Am J Surg 2009;197:660-5. [CrossRef]

23. Cuccia G, Mucciardi G, Morgia G, Stagno d'Alcontres F, Gali A, Cotrufo $\mathrm{S}$, et al. Vacuum-assisted closure for the treatment of Fournier's gangrene. Urol Int 2009;82:426-31. [CrossRef]

24. Yan-Dong L, Wei-Fang Z, Jian-Jun Q, Jian-Jiang L. Enterostomy can decrease the mortality of patients with Fournier gangrene. World J Gastroenterol 2014;20:7950-4. [CrossRef]

\section{ORIJIINAL ÇALIŞMA - ÖZET}

\section{Fournier gangreni: 25 hastanın geriye dönük analizi \\ Dr. Metin Yücel, ${ }^{1}$ Dr. Adnan Özpek, ${ }^{1}$ Dr. Fatih Başak, ${ }^{1}$ Dr. Ali Kılıç, ${ }^{1}$ Dr. Ethem Ünal, ${ }^{1}$ Dr. Sema Yüksekdağ, ${ }^{1}$ Dr. Aylin Acar, ${ }^{1}$ Dr. Gürhan Baş ${ }^{2}$}

${ }^{1}$ Ümraniye Eğitim ve Araştırma Hastanesi, Genel Cerrahi Kliniği, İstanbul

${ }^{2}$ Medeniyet Üniversitesi Tıp Fakültesi, Genel Cerrahi Anabilim Dalı, İstanbul

AMAÇ: Fournier gangreni akut gelişen, hızlı ve sinsi ilerleyen, tanı ve tedavide geç kalındığında yüksek oranda morbidite ve mortalite ile sonuçlanan acil cerrahi bir hastalıktır. Bu çalışma ile kliniğimizde Fournier gangreni tanısı ile takip ve tedavi edilen hastaların sonuçlarını irdelemeyi amaçladık. GEREÇ VE YÖNTEM: Bu çalışma, 20।0-20I5 yılları arasında Fournier gangreni tanısıyla ameliyat edilen hastaların geriye dönük taranması ile yapıldı. Hastaların tanısı fizik muayene ile konuldu. Genital, perineal ve perianal bölgede hassasiyet, endurasyon, siyanoz, gangren ve cilt altı krepitasyon saptanan olgular Fournier gangreni olarak kabul edildi. Resussitasyonu takiben agresif cerrahi debritman ve seçilmiş olgularda debritmana ilave olarak 'Vacuum Assisted Closure' (VAC) uygulandı. Gerekli durumlarda mükerrer debritmanlar yapıldı. Hastaların takip ve tedavi sonuçları analiz edildi. BULGULAR: Çalışmaya 25 hasta dahil edildi. Bunlardan I4'ü (\%56) kadın, I I’i (\%44) erkek olup yaş ortalaması 54.3 (dağıı, $27-82$ ) idi. Kadınların yaş ortalaması istatistiksel olarak daha yüksekti $(p=0.00$ I). Hastanede ortalama yatış süresi 21.4 gün, ortalama debritman sayısı 2.4 kez idi. Hastaların I3'ünde (\%52) perianal bölgede apse ve 20'sinde (\%80) diabetes mellitus tespit edildi. Hastaların tümünde geniş debritman, I6'sında (\%64) ise debritmana ilave olarak VAC uygulaması yapıldı. VAC uygulanan hastalarda hastanede ortalama yatış süresi ve ortalama debridman sayısı istatistiksel olarak daha yüksek bulundu (sırasıyla, $p=0.004, p=0.048$ ). Bir hastaya ostomi açıldı ve bir hasta mortal seyretti.

TARTIŞMA: Fournier gangreninde erken tanı, etkili resüsitasyon, agresif debritman ve uygun olgularda debritmana ilave olarak VAC uygulanması ostomi ihtiyacını, morbidite ve mortaliteyi azaltabilir.

Anahtar sözcükler: Agresif cerrahi debritman; Fournier gangreni; vakum yardımlı kapama.

Ulus Travma Acil Cerrahi Derg 2017;23(5):400-404 doi: 10.5505/tjtes.2017.01678 